http://dx.doi.org/10.12775/szhf.2014.008

\author{
Konrad SzOCIK
}

\title{
Krytyka religii pozytywnej w filozofii Hegla
}

\section{Wstęp}

Krytyczny stosunek Hegla do religii nie był stanowiskiem oryginalnym w jego epoce i wyrażał popularną wówczas tendencję polegającą na zaprzeczaniu absolutnej, świętej wartości religii historycznych. Na uwagę mogą zasługiwać liczne odwołania historyczne, w których Hegel usiłuje odkryć ekonomiczne, polityczne i społeczne uwikłania religii i instytucji Kościoła. Zdumiewa także siłą perswazji, zawdzięczając ją przede wszystkim powoływaniu się na odpowiednie fragmenty Nowego Testamentu, których celem jest wykazanie braku biblijnej legitymizacji dla instytucji Kościoła. Ten aspekt jego krytyki, któremu sporo miejsca poświęcił m.in. w Wykładach $z$ filozofii dziejów ${ }^{1}$, właściwie niczym nie różni się od analogicznej krytyki Kościoła uprawianej przez Kierkegaarda dwadzieścia lat później².

\footnotetext{
${ }^{1}$ W drugim tomie Wykładów z filozofii dziejów (tłum. J. Grabowski i A. Landman, Warszawa 1958) czytelnik może zapoznać się z zaskakująco radykalną i ostrą krytyką instytucji Kościoła, szczególne w epoce średniowiecznej, przegrywającą porównanie zarówno z ideami Nowego Testamentu, jak i odnową Reformacji.

${ }^{2}$ Por. K. Szocik, Krytyka instytucji kościoła i relacji kościót - państwo w filozofii Kierkegaarda, „Przegląd Filozoficzny. Nowa Seria”, nr 1 (65), Warszawa 2008, s. 101-109.
} 


\section{Podporządkowanie i zniewolenie wyznawcy jako punkt wyjścia każdej religii pozytywnej}

Istota zarzutów Hegla koncentruje się na pozytywności każdej religii objawionej (a więc nie tylko chrześcijaństwa, ale także judaizmu), polegającej na silnym związku dogmatów i etyczności z autorytetem, nakazem prawodawcy czy założyciela religii ${ }^{3}$. Tym samym wartość jednostki jako autonomicznego ustawodawcy moralnego zostaje zniesiona na rzecz biernego posłuszeństwa postulatom religijnym, rzekomo pochodzącym od Boga. Formułując zarzuty o pozytywny charakter religii chrześcijańskiej, Hegel nie krytykuje działalności Jezusa, lecz percepcję jego nauki, która uległa zafałszowaniu. Z subiektywnej religii moralności, jaką stanowiło pierwotne, nieskażone chrześcijaństwo (tzn. nauka Chrystusa) spadkobiercy uczynili obiektywną religię pozytywną, zastępując niezależność intelektu i woli podporządkowaniem autorytetowi ${ }^{4}$. Mimo skierowania głównego ciężaru oskarżenia pod adresem kolejnych wieków rozwoju chrześcijaństwa Hegel także w wypowiedziach Jezusa dostrzega elementy pozytywności, jednak usprawiedliwia ich użycie przez specyfikę jego słuchaczy, narodu żydowskiego, który całość swojego życia religijnego i politycznego legitymizował wolą Boga ${ }^{5}$. Konsekwencją takiego przekonania był obowiązek bezwarunkowego posłuszeństwa Bogu, który zamiary i oczekiwania wobec „swojego" narodu zawarł w świętych księgach oraz nauce kapłanó $w^{6}$, co niewątpliwie utrudniało zadanie głosicielowi idei indywidualnej moralności, nieodwołującemu się do żadnego zewnętrznego autorytetu, czyniącego jedyną prawomocną instancją rozum, wolę i moralną intuicję jednostki ${ }^{7}$. Dlatego, w ocenie Hegla, chcąc uzyskać posłuch wśród żydowskich

${ }^{3}$ G. W. F. Hegel, Pozytywność religii chrześcijańskiej, [w:] Pisma wczesne z filozofii religii, tłum. G. Sowinski, Kraków 1999, s. 159.

${ }^{4}$ Tamże, s. $160-170$.

5 „Mianowicie Jezus był sam dla siebie zmuszony wiele mówić o sobie, o swej osobie; skłaniał go do tego sposób, w jaki naród żydowski był skłonny do siebie cokolwiek dopuścić; Żydzi żywili najgłębsze przekonanie, że cały swój ustrój, wszystkie swe prawa religijne, polityczne i obywatelskie otrzymali od samego Boga." G. W. F. Hegel, Pozytywność religii chrześcijańskiej, [w:] Pisma wczesne z filozofii religii, s. 163-164.

${ }^{6}$,To było ich dumą, ta wiara ucinała wszelkie spekulacje i ograniczała się wyłącznie do studiowania świętych tekstów, a rolę cnoty zawężała do ślepego posłuchu wobec tych nakazów, których Żydzi nie nadali sobie sami." Tamże, s. 164.

7 „[...] - nauczyciel, który pośród wezwań swego narodu chciał zdziałać więcej, niż napisać nowy komentarz na ten temat, nauczyciel, który chciał przekonać swych rodaków, że nie wy- 
słuchaczy, Jezus musiał odwołać się do boskiego namiestnictwa, nieustannie podkreślać zgodność swojej nauki z boską wolą, czy wreszcie głosić boską naturę samego siebie ${ }^{8}$.

W tej perspektywie istotną rolę odegrały cuda dokonywane przez Jezusa. Jako że nauczanie o jednostkowej moralności i cnocie dla oczekującego militarnej i politycznej potęgi narodu żydowskiego nie mogło w żaden sposób uchodzić za interesujące, Jezus musiał uciec się do paru nadprzyrodzonych wydarzeń, tylko w ten sposób mogąc przykuć uwagę swoich słuchaczy ${ }^{9}$. Jednak o ile Jezus uciekł się do cudów jedynie jako marketingowego zabiegu, o tyle dla jego uczniów, narodu żydowskiego oraz kolejnych pokoleń wyznawców cuda stały się istotą nowej religii pozytywnej, uzasadniając boskie posłannictwo Jezusa ${ }^{10}$. Tym samym cnota, etyczność zostały zdegradowane na ostatnie miejsce: w odbiorze słuchaczy i późniejszych wyznawców cuda Jezusa legitymizowały jego boski autorytet, i dopiero wówczas Jezus mógł na drodze nakazu nadać ważność etyczności, która w przekonaniu odbiorców jego orędzia sama w sobie żadnej ważności nie posiadała ${ }^{11}$. Hegel przyznaje słuszność Jezusowi, wskazując na jego wyłącznie pedagogiczno-moralizatorskie intencje ${ }^{12}$; mentalność jego słuchaczy wymusiła konieczność akcentowa-

starcza przepisowa wiara kościelna, z konieczności musiał oprzeć swe twierdzenia na takim samym autorytecie; powoływać się jedynie na rozum znaczyłoby tyle samo, co wygłaszać kazanie do ryb, Żydom brakowało bowiem zrozumienia dla takich wezwań.” Tamże, s. 164.

${ }^{8}$ „[...] - gdyby nie stał za nim ten autorytet, Jezus nie mógłby wpłynąć na swych współczesnych nawet najbardziej wymownymi argumentami na temat cnoty samej w sobie; Jezus zapewne miał świadomość jakiegoś związku z samym Bogiem czy choćby tylko uważał wyryte w naszych sercach prawo za bezpośrednie objawienie Boga, że jest ono iskrą boskości, a mając pewność, że naucza tego jedynie, co nakazuje owo prawo, był świadom zgodności swej nauki z wolą Bożą." Tamże, s. 164.

${ }^{9}$ G. W. F. Hegel, Pozytywność religii chrześcijańskiej, [w:] Pisma wczesne z filozofii religii, s. 166.

10 „Zapewne nic tak bardzo jak owa wiara w cuda nie sprawiło, że religię Jezusa uczyniono religią pozytywną, że jej całość, w tym nawet naukę o znaczeniu cnoty, oparto na autorytecie." Tamże.

${ }^{11}$ „[...] przekonanie o zobowiązaniu do cnoty obrało teraz następującą drogę: cuda, przyjęte bez jakichkolwiek zastrzeżeń, uzasadniały wiarę, uzasadniały autorytet ich sprawcy, a ów autorytet ich sprawcy stał się zasadą zobowiązania do etyczności [...].” Tamże, s. 166-167.

„Teraz już nie Jezusowa nauka o cnocie miała stanowić sama dla siebie przedmiot szacunku, rodząc z kolei szacunek dla nauczyciela, lecz na odwrót, nauka o cnocie mogła się domagać szacunku jedynie z uwagi na nauczyciela, ten zaś z uwagi na swe cuda”. Tamże, s. 167.

12 „[...] sam Jezus domagał się wiary nie z uwagi na swe cuda, lecz z uwagi na swą naukę, i choć wieczne prawdy, jeśli mają być konieczne i powszechnie ważne, mogą znaleźć funda- 
nia nie tyle samej nauki o cnocie opierającej się wyłącznie na niezależnym ludzkim rozumie, co położenia nacisku na boskie uzasadnienie, które mogło zostać udowodnione jedynie za pomocą cudów. W przypadku Sokratesa, który podobnie jak Chrystus również był nauczycielem cnoty, stosunek osoby nauczyciela do etyczności prezentował się odmiennie: Sokratesa ceniono ze względu na jego moralność oraz poglądy filozoficzne ${ }^{13}$, podczas gdy w chrześcijaństwie Chrystus musiał nadać boską sankcję etyczności i bynajmniej nie uzyskał uznania wskutek swojego ubóstwa i prześladowań.

Cechą charakteryzującą religie pozytywne jest dążenie do ekspansji i popularyzowania własnej doktryny ${ }^{14}$. Pozytywność religii obiektywnej, czyli zestaw zasad i dogmatów przedstawianych jako bezdyskusyjnie nakazane przez Boga, urasta do najwyższej rangi, czyniąc etyczność i osobistą moralność sprawą o znaczeniu drugorzędnym lub wcale nieistotną ${ }^{15}$. Zamiast eksponować istotę misji Jezusa jako nauczyciela cnoty - głoszenie ideału miłości bliźniego - chrześcijanie ośrodkiem nowej religii uczynili zewnętrzne symbole, przede wszystkim chrzest, oraz wiarę ${ }^{16}$. Ten zwrot, będący wypaczeniem i zafałszowaniem wyłącznie moralizatorsko-pedagogicznej misji Jezusa, otworzył pole dla działań o ekonomiczno-materialistycznych celach. Hegel, podobnie jak Kierkegaard, wskazuje na brak jakiejkolwiek legitymizacji dla instytucji Kościoła w wypowiedziach Jezusa. A jako że Kościół stał się istotą religii chrześcijańskiej, krytyka religii pozytywnej w heglowskim wydaniu sprowadza się często do krytyki instytucji Kościoła. Niemniej, zanim Hegel przejdzie do uwag pod adresem funkcjonowania instytucji, analizuje niedostatki religii pozytywnej. Krytyka instytucji Kościoła w stosunku do krytyki samej religii pozytywnej ma charakter krytyki „drugiego rzędu”. Kościół jest nie tylko nieuzasadnionym tworem, ale nawet gdyby na podstawie innych ksiąg świętych (Hegel zdecydowanie wyklucza możliwość generowania przez

ment jedynie w istocie rozumu, a nie w przypadkowych dlań zjawiskach zewnętrznego świata zmysłowego [...].” Tamże, s. 166.

${ }^{13}$ Tamże, s. 169.

${ }^{14}$ „Inną cechą swoistą cechy pozytywnej jest zapał, z jakim stara się ona rozprzestrzeniać, z jakim szuka prozelitów dla swej wiary i nieba.” Tamże, s. 178.

${ }^{15}$ „[... [ albowiem czystość serca była dla was obu istotnym elementem waszej wiary, dlatego każdy mógł drugiego traktować jako towarzysza w swojej wierze. Ten natomiast, w którego oczach aspekt pozytywny jego religii ma nieskończoną wartość i którego serce nie potrafi ustanowić niczego wyższego nad tę pozytywność, do wyznawców innej sekty będzie się odnosić [...] albo z politowaniem, albo z obrzydzeniem.” Tamże, s. 179.

${ }_{16}$ Tamże, s. 171. 
Nowy Testament implikacji instytucjonalnych) posiadał rację bytu, nadal pozostaje wytworem religii pozytywnej, która jest mniej wartościowa od rozumowych religii subiektywnych, ponieważ nie odwołuje się do autonomicznej pracy intelektu i woli, ale przedstawia gotowe tezy, które bierny intelekt może jedynie przyjąć.

\section{Różnica między moralnością religii pozytywnej a subiektywnej}

Hegel wiąże funkcjonowanie wspólnot wyznających religię pozytywną $\mathrm{z}$ legalizmem. W religii moralności, subiektywnej, jak również w przypadku systemów filozoficznych jednostka sama określa zakres praw i norm, którym dobrowolnie się poddaje ${ }^{17}$; taki stan rzeczy panował również w pierwszych latach istnienia chrześcijaństwa, kiedy członkowie gmin wspólnie koncentrowali się na praktycznym doskonaleniu moralnie godziwego życia ${ }^{18}$. Natomiast w pozytywnej religii chrześcijańskiej to, co dobre, sprawiedliwe i słuszne jest już określone bądź przez wcześniejszy nakaz prawodawcy czy fundatora religii, bądź przez orzeczenia uprawnionych grup (sobory bądź decyzje papieży). W tym przejawia się podkreślana nieustannie przez Hegla deprawacja ludzkiego ducha, któremu nie pozostaje nic innego, jak tylko poddać się zewnętrznym, obcym nakazom ${ }^{19}$. Podporą legalistycznego charakteru etyki w religii pozytywnej jest dziedzictwo historyczne, którego głównym zadaniem jest determinowanie określonych postaw emocjonalno-intelektualnych

\footnotetext{
17 „[...] dzięki uznaniu tez jakiegoś systemu filozoficznego czy, w życiu praktycznym, dzięki cnocie człowiek staje się (w pierwszym przypadku) zwolennikiem danej sekty filozoficznej czy (w drugim) obywatelem królestwa etyczności, obywatelem niewidzialnego Kościoła, nie biorąc na siebie żadnych innych obowiązków niż te, które sam sobie nakłada, a społeczności takiej nie daje [innych] praw nad sobą niż te, które sam jej przyznaje." Tamże, s. 187.

18 „Pierwsi chrześcijanie, związani wspólną wiarą jako jednoczącym ich momentem, stanowili ponadto społeczność, której członkowie wzajemnie się zachęcali w swych postępach na drodze dobra i mocnej wiary, wzajemnie pouczali się o sprawach wiary i innych obowiązkach, razem rozwiązywali swe wątpliwości, utwierdzali chwiejnych, jeden zwracał drugiemu uwagę na jego błędy, przyznawał się do własnych, a swej skruchy, tak jak i swego wyznania, dokonywał na forum społeczności." Tamże, s. 187.

19 „[...] natomiast dzięki przystąpieniu do grona wyznawców chrześcijańskiej sekty pozytywnej przyjmował obowiązek posłuszeństwa wobec statutu chrześcijańskiej społeczności, nie dlatego, że sam uważał coś za zgodne z obowiązkiem, za dobre i pożyteczne, ocenę w tej sprawie [musiał bowiem] pozostawić społeczności i na gruncie cudzego nakazu i wglądu uznać coś za obowiązek; odtąd miał obowiązek wierzyć w coś, uznawać coś za prawdę, ponieważ społeczność nakazała mu w to coś wierzyć." Tamże, s. 187-188.
} 
wśród wyznawców, przede wszystkim wytworzenia absolutnego posłuszeństwa religijnym obowiązkom i postanowieniom Kościoła ${ }^{20}$. Hegel rzecz jasna nie mógł zaakceptować budowania systemu etycznego na podstawie określonych faktów historycznych (scen przedstawionych w Starym i Nowym Testamencie), które jako bezdyskusyjne i nie wyprowadzane z ludzkiego ducha mogą być jedynie pasywnie akceptowane przez jednostkę. W heglowskim ideale moralność powinna być rezultatem aktywności świadomości, konsekwencją refleksji ludzkiego ducha; Kościół chrześcijański wybrał jednak rozwiązanie odwrotne do heglowskiej propozycji, fundując etyczność na zbiorze historycznych reguł i wydarzeń $\mathrm{z}$ historii jednego narodu.

Jak wspomnieliśmy, w religii pozytywnej moralność nie jest autonomiczną wiedzą ducha, ale dostarczoną z zewnątrz gotową wiedzą, której jedynie można się nauczyć bądź po prostu w nią uwierzyćéc. Wydaje się, że religia pozytywna $z$ definicji nie może posiadać innego typu systemów etycznych jak tylko wynikające z nakazu; każde objawienie, moment założenia religii w historii obejmuje ufundowanie gotowej koncepcji etycznej. Hegel ponadto zauważa, że nie zachodzi jakakolwiek różnica w zakresie stopnia doskonałości moralnej między członkiem Kościoła religii pozytywnej a osobą wyznającą moralność religii subiektywnej, rozumowej ${ }^{22}$. Wielowiekowy wysiłek Kościoła nie wniósł niczego pozytywnego i konstruktywnego do moralno-duchowego dziedzictwa ludzkości, co jest kolejnym argumentem podważającym

\footnotetext{
20 „Punktem wyjścia jest poznanie historyczne, któremu wyznacza się, jakie ma generować doznania i jaki stan umysłu, mianowicie wdzięczność i strach - by utrzymać nas w wierności wobec naszych obowiązków, których kryterium stanowi podobanie się Bogu, kryterium znane w przypadku części obowiązków, natomiast sztucznie z wiedzy historycznej wykalkulowane w przypadku innych." Tamże, s. 221-222.

${ }^{21}$ „Kościelny system moralny opiera się na religii i na naszej zależności od Boga, co stanowi główną cechę tego systemu; fundamentem jego budowli nie jest jakikolwiek fakt z dziedziny naszego ducha, jakakolwiek teza, którą można by wywieść z naszej świadomości, lecz coś, czego się nauczono, moralność nie [pozostaje] zatem autonomiczną wiedzą, niezależną w swych zasadach; istota etyczności nie opiera się zatem na wolności, na autonomii woli.” Tamże, s. 221. ${ }^{22}$ „Gdy jakiś człowiek przebył całą drogę poznawania, doznawania i stanów umysłu, którą przepisuje Kościół, a jednak nie doszedł dalej niż ktoś, kto nie miał całego tego aparatu, tak jak wielu cnotliwych ludzi między tak zwanymi poganami, i [gdy] wprawdzie daleko zaszedł w lęku i ostrożności, podległości i posłuszeństwie, ale pod względem męstwa zdecydowania, siły i innych cnót, dzięki którym rzeczywiście można wspierać dobro jednostek i państwa, pozostał w tyle czy wręcz wyszedł z tej wędrówki bez niczego - to cóż zyskał ród ludzki dzięki mozolnemu systemowi reguł Kościoła?”. Tamże, s. 223.
} 
ważność i funkcjonalność religii pozytywnych ${ }^{23}$. Pozytywność chrześcijaństwa sformalizowana za pomocą instytucji Kościoła zniweczyła ideę wolności związaną z pierwotnym chrześcijaństwem. Kościelna polityka promowała poddaństwo wobec prawa, ślepe posłuszeństwo niweczące wolną refleksję intelektualną, tym samym upodabniając chrześcijan do narodu żydowskiego ${ }^{24}$. Obowiązki nałożone na chrześcijan opierają się na przymusie, ponieważ organem egzekwującym ich wykonywanie była groźba rozmaitych sankcji grożących niepokornym wierzącym ze strony duchownych, jak znane $\mathrm{z}$ historii ekskomuniki czy działalność inkwizycji ${ }^{25}$.

4. Eliminacja wolności i autonomii jednostki w religiach pozytywnych

Możemy dostrzec, że zinstytucjonalizowana religia pozytywna niwelowała jednostkową wolność dwojako: zmuszając swoich wyznawców do biernej afirmacji określonych tez (objawionych, zewnętrznych) oraz grożąc jednostce usposobionej refleksyjnie i krytycznie poważnymi konsekwencjami duchowo-psychicznymi (działanie diabła, wzbudzanie strachu przed piekłem) oraz fizycznymi (społeczne konsekwencje alienacji związanej z ekskomuniką, itp.). Jeżeli moralność zasadza się wyłącznie na zewnętrzności, a nie jest współtworzona przez jednostkę, nietrudno o różnorodne patologie w postaci dwuznaczności, hipokryzji i obłudy. Z jednej strony naturalnym dążeniem jednostki pozostaje pragnienie oszukania systemu wymagającego od niej określonych postaw i zachowań, $\mathrm{z}$ drugiej strony łagodzące duchowe niepokoje zapewnienie duchowieństwa, że gwarantem wiecznej nagrody w niebie nie jest (jak możnaby wywnioskować z lektury Nowego Testamentu) kultywowanie miłości bliźniego i samodoskonalenie moralne, ale wypełnianie poleceń Kościoła i udział w obrzędach.

Hegel wskazuje prawodawczą autonomiczność jednostki jako istotny przejaw człowieczeństwa. Zatem sytuacja Kościoła chrześcijańskiego (jak również wszystkich innych religii pozytywnych), który prawo moralne przedstawia w ukończonej i uformowanej przed wiekami postaci, wymagając jedynie ak-

\footnotetext{
${ }^{23}$ Tamże, s. 223-224.

${ }^{24}$ Tamże, s. 225.

${ }^{25}$ „[...] obowiązki religijne Żydów w pewnej mierze były także obowiązkami opartymi na przymusie, czym po części są one również w Kościele chrześcijańskim, albowiem ten, kto ich zaniedbuje, tu i ówdzie naraża się jeszcze na stos, niemal powszechnie zaś zostaje pozbawiony praw swego państwa." Tamże.
} 
ceptacji i wiary w ich boskie pochodzenie, uniemożliwia jednostce korzystanie z pełni człowieczeństwa ${ }^{26}$. Co więcej, jeśli uznać nakaz posłuszeństwa „obcemu”, zewnętrznemu w stosunku do naszej myśli i woli kodeksowi moralnemu za bezprawny, władza Kościoła nad swoimi wyznawcami również przedstawiałaby się jako bezprawna, pozostająca w sprzeczności z prawami ludzkiego rozumu $^{27}$. Zdaniem Hegla skłonność do wiary w panujący nad człowiekiem byt boski (na której opiera się religia pozytywna) wynika z uznania przewagi boskości nad sobą samym we wszystkich dziedzinach ${ }^{28}$. Konsekwencją aktualizacji takiej wiary jest wyrzeczenie się autonomii rozumu, ponieważ w sytuacji konfrontacji wierzącej jednostki z potężnym i absolutnym Bogiem ludzki intelekt pozostaje bez jakichkolwiek możliwości działania ${ }^{29}$. Pozostaje jedynie wiara, zaufanie w dobrość i miłosierdzie Boga, oczekiwanie na jego łaskę oraz posłuszeństwo poleceniom wydawanym przez Kościół, w którego gestii, jako wtajemniczonego i znającego oczekiwania Boga, znajduje się sposób na osiągnięcie niebiańskiej chwały.

\section{Chrześcijaństwo przyczyną degradacji kultury europejskiej}

Podobnie jak w odniesieniu do jednostki religia pozytywna spełnia funkcję ograniczającą i degradującą, tak też w stosunku do narodów uwydatniają się jej negatywne skutki. Najbliższe narodom są ich własne religie subiektywne, rozumowe, odzwierciedlające obyczaje, tradycję, jednym słowem specyfikę i własności danego narodu. Natomiast religia chrześcijańska jest obca kulturze europejskiej i zaszczepia narodom Europy odmienne prawa i oby-

${ }^{26}$ „Z prawa do tego, by samemu nadać sobie swe własne prawo, by tylko wobec siebie być winnym rozliczenia ze sposobu, w jaki nim operuje, żaden człowiek nie może zrezygnować, gdyż wyzbywając się go, przestałby być człowiekiem. Ale rzeczą państwa nie jest przeszkadzać mu w tym - działanie takie oznaczałoby, że państwo chce człowieka przymusić, by był człowiekiem, a to byłoby przemocą." Tamże, s. 230.

27 „Na posiadaniu tego kodeksu i operowaniu nim zasadza się wszelka władza prawodawcza i sędziowska Kościoła; a jeśli jest sprzeczne z prawem rozumu każdego człowieka, że podporządkowuje się go takiemu obcemu kodeksowi, to cała władza Kościoła pozostaje bezprawna.” Tamże.

${ }^{28}$ „Kto uznaje tę przewagę pewnej istoty nie tylko nad popędami swego życia - albowiem przewagę taką, pod nazwą „natury”, „fatum” czy „opatrzności” musi uznać każdy - ale również taką przewagę nad swym duchem, nad całym zakresem swego bycia, ten nie może uniknąć wiary pozytywnej." Tamże, s. 232.

${ }^{29}$ „Zdolność do takiej wiary nieuchronnie zakłada utratę wolności rozumu, jego samodzielności, która nie może niczego przeciwstawić obcej mocy." Tamże. 
czaje, właściwe narodom Bliskiego Wschodu, ale nie germańskim i słowiańskim mieszkańcom środkowej i wschodniej Europy ${ }^{30}$. Postulat związku religii z dziejami i naturą narodu wynika także z obserwacji praktyk obrzędowych i doświadczeń wiernych w chrześcijańskich państwach Europy, w których największym uznaniem darzono lokalnych świętych, z których kilku wybranych urastało do rangi czołowych patronów kraju ${ }^{31}$. Zatem, zgodnie $\mathrm{z}$ heglowskimi analizami, duch narodu manifestujący się w postaci religii nie ujawnia się $\mathrm{w}$ osobach bóstw odgórnie ustanawianych i importowanych $\mathrm{z}$ Bliskiego Wschodu, lecz w osobach regionalnych świętych, bliskich poszczególnym narodom. Chrześcijaństwo, jako religia pozytywna ufundowana na świętych księgach ludów Bliskiego Wschodu, nie przystaje do kultury narodów europejskich $\mathrm{z}$ racji całkowitej odmienności społeczno-historycznej zawartej w Starym i Nowym Testamencie, dlatego olbrzymie fragmenty Biblii będące rezultatem ludowej wyobraźni mogłyby zostać zastąpione mitycznymi wyobrażeniami społeczności europejskich ${ }^{32}$. Jedyne podobieństwa odnoszą się do wspólnej natury ludzkiej, jednak są niewystarczające dla zniwelowania zasadniczych różnic kulturowych ${ }^{33}$. W podobnym duchu wypowiadał się także Johann Herder, który przypisywał chrześcijaństwu zniszczenie tożsamości i kultury narodów europejskich, obwiniając zarówno bezwzględną politykę instytucji Kościoła, jak również obcą, odznaczającą się niską jakością i nie-

${ }^{30}$ „Chrześcijaństwo wyludniło Walhallę, wycięło święte gaje, a wyobraźnię ludu wytępiło jako haniebny zabobon, jako diabelską truciznę, zamiast tego dając nam wyobraźnię ludu, którego klimat, którego prawodawstwo, którego kultura, którego zainteresowania są nam obce, którego historia nie ma z nami żadnego związku." Tamże, s. 239.

31 „dla katolików znacznie bardziej obecne i bardziej ważne są te cuda, których dokonano w ich kraju, niż często znacznie większe, których jednak dokonano w innych krajach czy nawet których dokonał Chrystus. Zwykle każdy kraj ma swego patrona, który go strzeże i który zwłaszcza w tym kraju dokonywał cudów, ciesząc się w nim szczególną czcią. Ponadto, każdy naród wierzy, że jest na zasadzie prymatu wyróżniony i szanowany dzięki szczególnej uwadze, którą poświęcił mu taki strzegący go Bóg, przy czym ów prymat przed innymi narodami zwiększa doń przywiązanie, jak to widzimy w przypadku Żydów.” Tamże, s. 242.

32 „Wszystko, co w naszych księgach świętych jest historią we właściwym tego słowa znaczeniu - ogromna część Starego Testamentu - i co właściwie nie nakłada, jak Nowy Testament, obowiązku wiary, co zatem właściwie może się stać przedmiotem wyobraźni ludu, jest tak obce naszym obyczajom, naszemu ustrojowi, kulturze naszych sił fizycznych i psychicznych, że nie ma prawie punktu, w którym byśmy się z tym stykali, jeśli nie liczyć powszechnej natury ludzkiej, która tu i tam jest obecna.” Tamże, s. 242-243.

${ }^{33}$ Tamże, s. 243. 
zdolną do rozwoju ducha naukę i kulturę łacińską ${ }^{34}$. Chrześcijański rozum, który w ujęciu heglowskim pojawił się wśród „zepsutego" narodu żydowskiego i rzymskiego, poszukiwał absolutnych i niezależnych pierwiastków, które mogły zostać odnalezione jedynie w idei Boga, w przeciwieństwie do greckiej religii wyobraźni i rozumu, która elementy wieczności i autonomii umieszczała w człowieku ${ }^{35}$. Nadzieje pokładano wyłącznie w Bogu, rezygnując z odpowiedzialności i idei moralnego samodoskonalenia się, trwając w biernym stanie bezradności i oczekiwania na boską pomoc ${ }^{36}$.

\section{Zinstytucjonalizowane chrześcijaństwo zniekształciło idee nauki Jezusa}

Ideowi spadkobiercy Jezusa do tego stopnia sprzeniewierzyli się jego nauczaniu, że zamiast wcielać w życie oparty na wolności ducha ideał miłości bliźniego, zabsolutyzowali pewne całkowicie przypadkowe elementy jego życia i działalności, nieuzasadnienie wyprowadzając z nich nakazy i reguły, posłuszeństwa wobec których rzekomo miałby oczekiwać sam Bóg ${ }^{37}$. Tym samym to, co w życiu Jezusa było zupełnie przypadkowe, a zatem mogło potoczyć się w inny sposób bądź w ogóle się nie zdarzyć, zostało uznane za coś świętego, wymagającego oddawania boskiej czci ${ }^{38}$. W tej sytuacji nadanie wybranym znakom, obrzędom czy gestom magicznej rangi, a w konsekwencji uznanie ich realizowania czy nakaz posłuszeństwa wobec nich czyniąc istotą nowej religii, doprowadziło do przeniesienia ciężaru odpowiedzialności za indywidualne zbawienie z jednostkowego samodoskonalenia się na wierność

${ }^{34}$ Z. Skuza, Filozofia antropologiczna Herdera, [w:] J. G. Herder, Myśli o filozofii dziejów, Warszawa 2000, s. 28.

${ }^{35}$ G. W. F. Hegel, Pozytywność religii chrześcijańskiej, [w:] Pisma wczesne z filozofii religii, s. 250 .

${ }^{36}$ „wymiar taki ukazywał się rozumowi jeszcze w Bogu, którego oferowała mu religia chrześcijańska, poza sferą naszej mocy, naszego chcenia, ale nie poza sferą naszych błagań i próśb urzeczywistnienia idei moralnej można było zatem już tylko sobie życzyć (rzeczy bowiem, której może sobie życzyć, człowiek nie może samemu spełnić i oczekuje, że ją uzyska bez własnego współudziału), a nie chcieć." Tamże, s. 250.

${ }^{37},[\ldots]$ natomiast jego następcy wyrzekają się żydowskich przypadkowości, ale nie oczyszczają się z ducha zależności od tego rodzaju elementów w ogóle; niebawem z mów Jezusa, z epizodów, które przydarzyły się jego osobie, wywodzą dla siebie reguły, nakazy powinności, a wolne naśladownictwo nauczyciela przemienia się w poddańczą służbę wobec mistrza." Tamże, s. 274.

${ }^{38}$ Tamże. 
tymże obrzędom i nakazom, mającym rzekomo zagwarantować okupienie grzechów i życie wieczne po śmierci ciała.

\section{Zakończenie}

Przekonanie o radykalnym rozłamie miedzy działalnością Jezusa a zinstytucjonalizowanym chrześcijaństwem jest motywem popularnym w niemieckojęzycznym piśmiennictwie XVIII i XIX wieku. Oprócz Hegla wymienić można m.in. Lessinga, który eksponując sferę ducha i praktycznej moralności krytykował utożsamianie prawd historycznych z prawdami wiecznymi, deifikowanie instytucji, obrzędów, itp. Podobnie przywoływany Kierkegaard, czerpiący inspiracje m.in. z filozofii heglowskiej, był jednym z najzagorzalszych krytyków instytucji Kościoła. Co ciekawe, miażdżącej krytyce poddawał luteranizm, który w przeciwieństwie do Kościoła rzymskokatolickiego zachowuje wymiar instytucjonalny w minimalnym stopniu.

Ważnym czynnikiem kształtującym postawę krytycyzmu niemieckojęzycznych filozofów wobec chrześcijaństwa zinstytucjonalizowanego było wyznawanie, a przynajmniej wychowanie w kulturze protestanckiej. Poglądy Hegla należy wprawdzie odczytywać inaczej niż np. Kierkegaarda czy Lessinga. Hegel był myślicielem ateistycznym i krytyka religii, Kościoła i samego istnienia Boga jako bytu transcendentnego jest nieuniknioną konsekwencją jego ateistycznej, czysto antropologicznej filozofii ducha ludzkiego. Niemniej pierwsze pisma odpowiadały nurtowi prowadzonej w duchu protestantyzmu krytyki instytucjonalizacji chrześcijaństwa.

Jaką ważność dzisiaj posiada heglowska krytyka sprzed dwustu lat? Dla ateisty będzie kolejnym argumentem przemawiającym na rzecz konieczności rezygnacji z podzielania przekonań religijnych, które są jedynie „zabobonem”, „przesądem” dziedziczonym bezrefleksyjnie z pokolenia na pokolenie. Dla osób wierzących może stanowić pewien kłopot. Dla wierzącego związanego z instytucją Kościoła w zasadzie pozostają dwa rozwiązania. Jednym jest dopisanie Hegla do indeksu ksiąg zakazanych jako heretyka i bluźniercy, co z urzędu rozwiązuje problem. Druga możliwość wiązałaby się z przyjęciem krytycznej postawy wobec dziejów i genezy własnej religii, przede wszystkim jej wymiaru instytucjonalnego. Hegel wskazuje, podobnie jak m.in. przywoływani Kierkegaard czy Lessing, na konkretne praktyki i wydarzenia historyczne, eksponujące olbrzymi udział (w ich mniemaniu wyłączny) czynnika czysto ludzkiego, a nie boskiego w tworzeniu religii i Kościoła. Taką krytykę 
można zignorować i odrzucić lub spróbować odnaleźć w niej zachętę do pewnej dozy krytycyzmu i refleksyjności wobec własnych przekonań.

W najlepszym położeniu znajduje się czytelnik wierzący w istnienie Boga, który podziela zaprezentowaną krytykę (może nie we wszystkich punktach), zdając sobie sprawę z niekoniecznie boskich inspiracji kierujących twórcami podstaw religii i instytucji. Niezależnie natomiast od osobistego stosunku wobec heglowskiej (reprezentatywnej zresztą dla sporej grupy myślicieli) krytyki religii pozytywnej jej wartość polega na doskonałym wpisaniu się $\mathrm{w}$ procesy sekularyzacji, występujące przede wszystkim w Europie Zachodniej, a dochodzące do głosu również w Polsce. Pomijając ateizm czy sceptyczne, agnostyczne ustosunkowanie się do możliwości istnienia Boga, wiele osób, wychowanych w kulturze szacunku dla Kościoła i religii często odstępuje od udziału w życiu i praktykach instytucji Kościoła. Jako argumenty nieświadomie przytaczają zarzuty identyczne z tymi, które przed dwoma stuleciami zostały precyzyjnie i rzetelnie sformułowane przez Hegla, Lessinga czy Kierkegaarda.

\section{Bibliografia}

Hegel G. W. F., Pisma wczesne z filozofii religii, tłum. G. Sowinski, Kraków 1999.

Hegel G. W. F., Wykłady z filozofii dziejów, tłum. J. Grabowski i A. Landman, Warszawa 1958.

Herder J. G., Myśli o filozofii dziejów, Warszawa 2000.

Szocik K., Krytyka instytucji kościoła i relacji kościół - państwo w filozofii Kierkegaarda, „Przegląd Filozoficzny. Nowa seria”, 2008, nr 1 (65), Warszawa 2008, s. 101-109.

\section{Abstract \\ The Critique of Positive Religion in Hegel's Philosophy}

This paper recalls a less known aspect of Hegelian philosophy of religion consisting in the radical critique of Christendom. Hegel criticized first of all Roman Catholic Church unlike Protestantism. Hegel underlined no biblical legitimization of church institution and therefore interpreted Christianity as a voluntary association but not as a mass institution. He also indicated negative implications of positive religion's ethics. His views were characteristic for critical philosophy of religion developed 
since the $17^{\text {th }}$ (Spinoza, Hobbes) till the $19^{\text {th }}$ century (David Strauss, Bruno Bauer, Ludwig Feuerbach, Karol Marks).

Today Hegel's views may be relevant in debates on political secularization explaining genesis of important stream in Western Europe which questions meaning of authorities especially religious.

Key words: Critique of religion, atheism, Christianity and Christendom, morality, ethics 